\title{
Do rich households live farther away from their workplaces?
}

Gutiérrez-i-Puigarnau, Eva; Mulalic, Ismir; Van Ommeren, Jos

Published in:

Journal of Economic Geography

Link to article, DOI:

10.1093/jeg/lbu046

Publication date:

2016

Document Version

Peer reviewed version

Link back to DTU Orbit

Citation (APA):

Gutiérrez-i-Puigarnau, E., Mulalic, I., \& Van Ommeren, J. (2016). Do rich households live farther away from their workplaces? Journal of Economic Geography, 16, 177-201. https://doi.org/10.1093/jeg/lbu046

\section{General rights}

Copyright and moral rights for the publications made accessible in the public portal are retained by the authors and/or other copyright owners and it is a condition of accessing publications that users recognise and abide by the legal requirements associated with these rights.

- Users may download and print one copy of any publication from the public portal for the purpose of private study or research.

- You may not further distribute the material or use it for any profit-making activity or commercial gain

- You may freely distribute the URL identifying the publication in the public portal

If you believe that this document breaches copyright please contact us providing details, and we will remove access to the work immediately and investigate your claim. 


\title{
Do rich households live farther away from their workplaces?
}

\author{
Eva Gutiérrez-i-Puigarnau \\ VU University, Amsterdam, The Netherlands \\ egutierrez@feweb.vu.nl \\ Jos van Ommeren \\ VU University, Amsterdam, The Netherlands \\ j.n.van.ommeren@vu.nl
}

$13-2-2012$

Abstract

One of the classic predictions of the urban economic theory is that high-income and low-income households choose different residential locations and therefore, conditional on workplace location, have different commuting patterns. Empirical tests of this theory are not standard, due to reverse causation and lack of good control variables. In the current paper, estimates of household income on commuting distance are derived using residential changes in distance for a given workplace, so reverse causation is eliminated. Our results show that the long-run income elasticity of commuting distance is positive and around 0.18 . The results suggest that the elasticities are higher for single wage-earners than for dual wage-earners and higher for females than for males.

Keywords: commuting, income elasticity, wage

JEL codes: J3, R21 


\section{Introduction}

Arguably, the centrepiece of urban economics is its elegant application of equilibrium analysis to land rent theory (Persky, 1990). Urban economic theory predicts that individuals with high incomes have different commuting patterns than those with low incomes. However, there has been a good deal of contention over the exact nature of this relationship. Empirical tests of this theory are not standard, due to reverse causation and lack of good control variables. The current paper aims to examine the long-run causal effect of income on the workers' commute.

The basic urban economic model argues, based on a monocentric city model (so, workplace is given), that those with higher incomes will have longer commuting distances (Alonso, 1964; Muth, 1969). Essential assumptions in this model are that employment is constrained in one location, monetary commuting costs depend on distance, ${ }^{1}$ and workers may freely choose the optimal residence location. Furthermore, it is assumed that house prices are endogenous and workers are homogeneous in all aspects except for (labour) income (Straszheim, 1987). Finally, the standard urban model is a static model which assumes away the presence of residential moving costs (one exception is Zenou, 2009), so it essentially deals with the long-run effect of income on residential location decisions.

The resulting effect of income on the commuting distance is then the result of two underlying mechanisms: $(i)$ a higher income leads to an increase in demand for housing and therefore for more residential space, and $(i i)$ house prices per $\mathrm{m}^{2}$ fall with distance from the employment centre. Consequently, in equilibrium, high-income households have a longer commute (e.g. Brueckner, 2000).

Although elegant, it appears that this intuitive result does not hold when some of the more restrictive assumptions are relaxed. For example, the unambiguous positive effect of income on commuting distance does not hold when commuting costs not only depend on monetary costs but also on commuting time. In time-extended urban economic models, which assume that the workers' commuting costs include time costs that positively depend on income, the effect of income on commuting distance is ambiguous (e.g. Beckman, 1974; Hockman and Ofek, 1977; Henderson,

\footnotetext{
${ }^{1}$ Commuting time does not play a role.
} 
1977; Fujita, 1989, p. 31). ${ }^{2}$ To be more precise, the effect of income on commuting costs depends on the difference between the income elasticity for residential space and the income elasticity for commuting costs. The only empirical study of are we are aware of finds that the income elasticities of residential space and generalised commuting costs are about equal (Wheaton, 1977). This implies that the overall effect of income on commuting distance is close to zero, and the relationship between income and residential space should be explained by other factors than commuting, such as residential amenities (e.g. Brueckner et al., 1999). Allowing for endogenously-chosen speed levels (through changes in travel mode) implies that higher income workers choose higher speed levels, so income-related differences in the length of the commute are likely more pronounced in terms of distance than of time.

Extending the standard model in other directions, for example allowing for more than one employment centre generally complicates matters, as the spatial distribution of wages, and therefore income, is endogenously determined in equilibrium (e.g. Fujita and Ogawa, 1982; White, 1988; Lucas and Rossi-Hansberg, 2002). In essence, however, the general idea that workers trade-off housing prices and commuting costs, and that the level of income determines housing demand and therefore the length of the commute remains in these models.

Allowing for two-earner households that work in the same workplace location (e.g. the Central Business District) does not fundamentally change the idea that workers trade-off house prices and commuting costs. For example, given the assumption that the demand for housing depends only on household labour income (and not the amount of leisure time which differs between one and twoearner households) and the value of travel time for each worker is proportional to wages, then an increase in wages and therefore household income will have similar effects on the length of the commute for single earner and two-earner households. Another more important extension in this context is to allow for two-earner households that do not work in the same workplace location (White, 1977). A typical example is that one wage earner commutes to the CBD, whereas the other wage earner commutes to a workplace in the suburbs (at the edge of the city). It is then perfectly possible that a change in residential location towards the central business district reduces the

\footnotetext{
${ }^{2}$ It is theoretically possible that increases in income first move the household away from employment centres, but beyond a certain point closer to the centre indicating a non-monotonous relationship between income and commuting (e.g. Fujita, 1989).
} 
commuting distance for one wage earner but increases the commuting distance for the other wage earner. So, the average effect of household income on commuting distance for a worker who belongs to two-earner households is then zero, independent of the direction of the residential move. Hence, any empirical test of the standard urban economic model must ideally distinguish between singleearner and two-earner households. Furthermore, it implies that the analysis of the income-distance relationship for single-earner households must be used as the pure test of the standard urban economic model.

Despite the large theoretical debate around these issues, and the extensive discussion of this topic in urban economics textbooks (e.g. O'Sullivan, 2009), there are no accurate empirical estimates of the causal effect of income on the commute. Previous studies do not make a distinction between two-earner and single-earner households and rely on cross-section estimates (e.g. White, 1977; Rouwendal and Rietveld, 1994), which makes a causal interpretation problematic. As far as we are aware, there are currently three studies which use panel data and estimate models with workers fixed effects (Benito and Oswald, 1999; Van Ommeren et al., 1999; Simonsohn, 2006). ${ }^{3}$ Although the use of fixed effects may reduce some of the endogeneity issues, these studies still have severe limitations.

First, although panel studies deal with time invariant unobserved worker characteristics, they do not deal with reverse causation as labour market theories indicate that the length of the commute affect wages. For example, as explained in detail later on, it is plausible that firms located at locations far from residences compensate their workers with higher wages. For example, Simonsohn (2006) writes "Most of the [ ] parameter estimates are hard to interpret, as [] higher incomes may increase opportunity costs of time (decreasing desired commute length) but may also be the result of compensatory wages for longer commutes."

Second, these studies identify short-run effects of household income rather than the long-run effects urban economic theory is interested in. Due to the presence of residential moving costs, even when experiencing a large change in household income, few workers will immediately change commuting distance by moving residence, so one expects that the long-run effect may be an order of magnitude larger than the short run effect. So, it seems that the current literature is not informative about the long-run causal effect of income on commuting. ${ }^{4}$

\footnotetext{
${ }^{3}$ A general finding is that the effect of income on commuting distance is small but positive.

${ }^{4}$ In the current paper, we will deal with the above issues by estimating reduced-form models. Hence, we cannot relate our
} 
The current paper aims to fill this gap in the literature by examining the long-run causal effect of household income on the length of the commute. Using annual panel data, our approach essentially entails analysing the effect of changes in income on changes in commuting distance which occur during a period of at least five years for workers who during this period stayed at the same workplace and moved residence at least once. In this way, we deal with time-invariant unobserved worker characteristics, reverse causation and identify long-term effects.

The next section shortly discusses two alternative (labour market) theories which may give rise to reverse causation. We explicitly discuss these theories because we aim to avoid reverse causation. We will also explain why standard instrumental variables IV approaches do not work. Section 3 introduces the identification strategy and the specification of the model, information on the data employed and presents the empirical results. Section 4 concludes.

\section{Theories which explain an income-commuting relationship}

As emphasised above, one of the predictions of urban economic models is a causal relationship between household income and commuting distance, because the endogenously chosen location of the residence depends on income. We will focus on single-earners. In essence, in addition to the explanation proposed by urban economic theory, there are two alternative labour market theoretical explanations for a relationship between income and commuting distance.

First, given a competitive labour market, firms located at locations far from residences compensate their workers with appropriately higher wages, which implies a spatial wage gradient (e.g. Fujita et al., 1997). This idea is confirmed by empirical findings (Timothy and Wheaton, 2001). These empirical findings are consistent with urban economic theory, but they do not tell us anything about the causal effect of income on the length of the commute through variation in residence location.

Second, in imperfect labour markets (e.g. a labour market characterised by incomplete information about job offers), the workers' commute is positively related to wages, because, given the residence location, jobs far away are more likely to be accepted if they offer higher wages (Manning,

findings directly to more fundamental properties of a structural urban economic model, such as Wheaton (1977). However, our study is the first one which deals with three fundamental difficulties - unobserved heterogeneity of workers, the presence of residential moving costs and a reverse causational relationship of income and distance - which have not been properly addressed in the literature. 
2003). Also given monopsonistic labour markets, workers with a longer commute are more likely to receive compensation from the employer, because they bargain from a less advantageous position (Van Ommeren and Rietveld, 2005). So, there is therefore simultaneity between the determination of wages and commute, due to search imperfections when workers change job, which also implies reverse causation.

In addition to these labour market theories, we have to deal with endogeneity due to unobserved variables. The standard argument is here that unobserved variables (e.g. skills) may affect both income and the commute, causing spurious correlation between income and the commute (for empirical evidence, see, in particular, Manning, 2003). Hence, due to the presence of wage gradients, job search imperfections, and unobserved variables, it appears that based on a standard a regression of commuting distance on household income (with controls), the effect of income on the commute is difficult to interpret as a causal effect of household income. A common method of dealing with these endogeneity difficulties is IV estimation. One problem with this approach is finding suitable instruments for the household income variable, as emphasised by Manning (2003). ${ }^{5}$ In essence, one must find an instrument that affects household income but not workplace location. In particular for single wage-earners, this turns out to be difficult as for single wage-earner households, household income and wage are essentially the same (and wages depend on workplace location). This is unfortunate, because as emphasised above, we are mainly interested in single wage earners. ${ }^{6}$

Rather than relying on an IV approach, we will use an approach that relies on the idea that according to the labour market theories which may cause reverse causation, the commute affects labour income only when changes in workplace location occur. So, in our analysis, we aim to keep job location constant; commuting distance may then only change through a residential move (or measurement error). In this way, we avoid the main sources of reverse causation. ${ }^{7}$

\footnotetext{
${ }^{5}$ Manning (2003) re-examines the results by Benito and Oswald (1999) and finds that the IV approach used by Benito and Oswald (1999) is sensitive to the choice of the instruments. Note that the use of educational level as an instrument for household income, which is common in the demand for residential space analysis (Glaeser et al., 2008), is not appropriate, as educational level has a (strong) effect on the job arrival rate and therefore on the observed commute.

${ }^{6}$ For two-earner households, one may argue that the income earned by the other wage-earner in the household is an appropriate instrument.

${ }^{7}$ It is theoretical possible that employers increase wages if workers move residence farther away from the job. Manning (2003) argues that this phenomenon is not relevant in the UK. Rouwendal and van Ommeren (2007) find some evidence
} 


\section{Empirical Analyses}

\subsection{Methodology}

In our analysis, we assume a standard reduced-form specification of commuting distance for a worker $i$ at time $t$ :

$\log D_{i t}=\beta_{0}+\beta_{1} \log Z_{i t}+\beta_{2} X_{i t}+S_{i}+u_{i t}$,

where $D$ denotes the commuting distance, $Z$ denotes the household income. Furthermore, $X_{i t}$ denotes exogenous time-varying controls for household and work characteristics and $S_{i}$ is a time-invariant controls; $u_{i t}$ is the overall error term. The coefficients $\beta$ are unknown, and our main interest is in $\beta_{1}$.

Observe that (1) is formulated as a static panel data model. ${ }^{8}$ Consistent estimation of $\beta_{1}$ requires that income is exogenous. Thus, the level of income is the result of the chosen job at the workplace location. In order to avoid reverse causation, we keep workplace location constant by following workers over time until they change workplace. Hence, in our analysis, we will only use variables which are formulated as changes over time (e.g. a change in household income). So, we will rewrite (1) as follows:

$$
\log D_{i t}-\log D_{i s}=\beta_{1}\left[\log Z_{i t}-\log Z_{i s}\right]+\beta_{2}\left[X_{i t}-X_{i s}\right]+u_{i t}-u_{i s},
$$

where $t>s$, and where the worker has not changed workplace between $t$ and $s$.

The observed time for a worker at the same workplace location will be called the workplace spell (and which will be censored when worker stopped answering the survey before changing workplace). ${ }^{9}$ In line with standard arguments, by using (2), one also addresses the endogeneity issue due to time-invariant unobserved worker characteristics (e.g. educational level which affects and length of the commute). Consequently, by using (2) we avoid endogeneity due to reverse causation and unobserved heterogeneity.

for The Netherlands that wages (excluding explicit reimbursement) do not increase, but explicit reimbursement rules regarding commuting costs imply that workers receive some compensation. Because Germany, which is the focus of our analysis, has similar compensation rules as The Netherlands, we may overestimate the effect of income on distance. We will, however, demonstrate later on that the bias is probably small.

${ }^{8}$ Formulating the model as a dynamic panel data model (so, past commuting distance is used as an explanatory variable) is not helpful, because commuting distance changes are infrequent, and one needs several changes in commuting distance per worker to identify such a model.

${ }^{9}$ Note that for some workers we only observe one workplace spell (workers who never change workplace during the period of observation) whereas for other workers, we observe several workplace spells (as workers switch jobs). 
As is well known for (static) panel data models, when variables are formulated as changes over time for short periods (e.g., $t-s$ is one year), one obtains the effect of the explanatory variables on the dependent variable that is almost immediate (e.g. within one year). Hence, it is a short-run effect, whereas we are interested to estimate the long-run effect of changes in household income. ${ }^{10}$

By focusing on changes in household income over longer time periods, we are more likely to capture the long-run effect of permanent changes in income in which we are interested. By construction, the maximum duration for which we can observe a household income change (without a change in workplace location) is the workplace spell. So, we will only employ changes in variables observed between the beginning and end of each workplace spell. Hence, to estimate the long-run effect of income on distance, we estimate models based on the following equation:

$\log D_{i t_{B}}-\log D_{i t_{E}}=\beta_{1}\left[\log Z_{i t_{B}}-\log Z_{i t_{E}}\right]+\beta_{2}\left[X_{i t_{B}}-X_{i t_{E}}\right]+u_{i t_{B}}-u_{i t_{E}}$,

where subscripts $t_{B}$ and $t_{E}$ denote the time at the beginning and the end of a workplace spell. Hence, per workplace spell we only use two observations (and calculate differences for these observations). ${ }^{11}$ For some workers, observed workplace spells in our data are still quite short. So, we will focus on results for workplace spells that are at least five years and compare these results with shorter workplace spells.

In order to interpret the estimated coefficient $\beta_{1}$ as a long-run effect of household income, households must have been able to freely choose a residence location when experiencing a change a in household income (while staying at the same workplace). However, there is ample evidence that households face substantial residential moving cost (Weinberg at al., 1981; Van Ommeren and van Leuvensteijn, 2005). As a result, households that experience a change in household income and therefore prefer to change their commute will usually not move residence, so commuting distance

\footnotetext{
${ }^{10}$ For example, if income increases one year and decreases the following year by the same amount, annual measures of change in income capture transitory changes in income. Using changes in transitory income rather than changes in permanent income most likely results in downward biased income estimates, in a similar way as measurement error would downward bias the estimates.

${ }^{11}$ Using only two observations per workplace spell has also the advantage that it allows for any form of serial correlation between $u_{i t}$ and $u_{i s}(t \neq s)$.
} 
will not change. ${ }^{12}$ Estimates based on (3) are therefore unlikely to generate the long-run effect of household income, because most workers will not change residence (within the period defined by a workplace spell).

Workers who have moved residence have been able to freely choose the residence location. In contrast for workers who have not moved residence, the commuting distance has not changed, so $\log D_{i t_{B}}-\log D_{i t_{E}}=0$. Clearly, if one would estimate (3) using only observations for workers who have not moved residence within a certain workplace spell, all coefficients $\beta$ would all be biased towards zero. This indicates that by including non-movers in the estimation procedure, one strongly biases the long-run effect towards zero. ${ }^{13}$ Hence, we estimate (3) using observations of workers who moved residence during the workplace spell, i.e. workers who are free to choose the distance from their residence to the workplace. See Figure 1 for examples of workplace spells that are included or excluded in the estimation approach.

Up to this point, for convenience, we assumed that workplace changes are observed. However, in most panel data sets the exact workplace location is unknown for reasons of privacy. Fortunately, it is usually straightforward to determine in most surveys in which period workplace location has not been changed. It is noted that when a worker does not change employer and does not change of type of job, it is almost always true that the worker did not change workplace location. One complication is firm relocations. However, we can also account for the possibility that some workers may change workplace location while staying with the same employer as the firm relocated to another location those. If a worker does not change employer or type of job (and does not change residence) while a change in commuting distance is observed in the data, then the worker must have changed workplace location because the employer has relocated the firm which has induced the workplace location change. These changes in workplace location due to firm relocation have been shown to be quite common, see Gutiérrez-i-Puigarnau and van Ommeren, 2010). We deal with this issue by excluding workplace spells which refer to these observations.

\footnotetext{
${ }^{12}$ For example, given an increase in household income, households may be inclined to occupy a larger residence at a larger commuting distance, but due to moving costs households may decide not to move, but to wait for another increase in income and then to move residence.

${ }^{13}$ In Germany, the annual residential moving rate is one of the lowest of Europe, and is about $7 \%$. This suggests that by including non movers, there will be a downward bias of $93 \%$.
} 


\subsection{Data}

Our study is based on information from fifteen waves of the 1990-2009 German Socio-Economic Panel (SOEP). For the years 1991, 1992, 1994 and 1996, information on commuting distance is missing, hence these years are excluded. ${ }^{14}$ The data contains information on household income (including non-labour income), worker income, whether a partner is present in the household, monthly workhours, whether the partner is employed, income of other household members for twoearner households, net hourly wage, ${ }^{15}$ number of children, age, gender, education, type of employee, residence region and provinces, workplace region, and firm size. We have information about when workers change residence, change of type of job (while staying with the same employer), or change employer.

\subsection{Selection of sample and descriptive statistics}

We focus on samples of workers aged between 20 and 60 with a positive commute. We have a sample of 52,742 annual observations; this contains 23,253 observations of one-earner households and 29,489 observations of two-earner households.

In our data selections, we follow exactly the approach explained in section 3.1. We analyse changes over time, so we have excluded observations for workers who are observed only once in the whole dataset. We also exclude observations of workers for the years that they change commuting distance but do not change residence, job type or employer. These observations refer either to firm relocations or measurement error in changes in commuting distance. ${ }^{16}$ We are then left with 19,485 workplace spells. For these spells, we use information of the first and the last time of observation for a given workplace spell (see equation (3)).

We impose that households must move residence. So, our main analysis will be based on a selective sample for which holds that at least one residential move has been made during the workplace spell. We are then left with 4,957 workplace spells for 4,702 workers (of which $41 \%$ are

\footnotetext{
${ }^{14}$ For the data extraction from the SOEP dataset, we used the PanelWhiz program (Haisken-DeNew and Hahn, 2010).

${ }^{15}$ Hourly wage rates are calculated by dividing net monthly income by actual monthly workhours.

${ }^{16}$ So, if distance changes in year $t$ but residence location does not change in year $t$, then the observation for a worker with the same job and employer for year $t$ is dropped. Changes in commuting distance due to an employer-induced workplace relocation may still play a role if this occurs within the same time period as a residence relocation, but this may only occur with a very small probability.
} 
females). The mean workplace spell is 3.9 years. The descriptive statistics of the samples imposing or not imposing a residential move are almost identical, suggesting that sample selection is not an issue (see Appendix A, Table A1). ${ }^{17}$

In the selective sample, mean household income is of $€ 3,756$, see Table A1. The mean one-way daily commuting distance, conditional on residence move, is $17.15 \mathrm{~km}$ in line with a range of other studies; hence our sample selection is likely unrelated to commuting behaviour. As expected, females in the sample have shorter distances and lower labour incomes than males. Workers belonging to oneearner households have about the same distance but lower household income than those belonging to two-earner households. The mean distance increases by income quartile: from $14 \mathrm{~km}$ for those with the lowest incomes (first quartile), $15 \mathrm{~km}$ for those in the second quartile, $16 \mathrm{~km}$ for those in the third quartile, to $18 \mathrm{~km}$ for the highest earners (fourth quartile). This suggests a rather strong positive relationship. A focus on changes over time shows that this is largely a spurious relationship. The correlation of changes in log distance and changes in log income is positive and equal to 0.03 .

It appears to be useful to distinguish between short workplace spells which may reflect shortrun behaviour and long workplace spells, which are more likely to capture long-run behaviour. We define long-run when the spell is at least 5 years and short-run when it is less than 5 years. The average time difference for long-run spells is 8.3 years, versus 2.7 years for short-run spells. As one may expect, the correlation of changes in log distance and changes in the income is higher for long spells (0.04) than for short spells (0.01). In Figures 2 and 3, one can observe the relationship between changes in log distance and changes in log household income graphs for short and long spells.

\subsection{Estimation results}

\subsubsection{Main Results}

The econometric results of several group fixed-effects models based on equation (3) are shown in Table 1 . The estimated income elasticity on distance is positive and around 0.11 , with a standard error of around 0.04 , see column [1]. This indicates that a higher income induces households to relocate farther away from the household members' workplaces. The size of the effect is not negligible. For

\footnotetext{
${ }^{17}$ We are anyway not too worried about any bias in the estimates due to this selection: a similar approach is (implicitly) taken in the hedonic pricing literature which uses data on housing transactions and therefore identifies demand for housing by households which move residence.
} 
example, given a daily mean commuting distance of $17.15 \mathrm{~km}$, a $100 \%$ increase in income increases the commuting distance by $1.32 \mathrm{~km}(0.7 \times 0.11 \times 17.15 \mathrm{~km}) .{ }^{18}$ The positive effect of income on distance is in line with previous (non causal) studies in the literature (Benito and Oswald, 1999; Van Ommeren et al., 1999; Simonsohn, 2006).

We have experimented with other specifications for income, but results are very similar to the results using the logarithm of income. For example, given a linear specification of income, the estimate for household income is 0.021 (s.e. 0.010), which corresponds to an elasticity of 0.080 (evaluated at mean household income of $€ 3,756$ ).

We further examine the results by distinguishing between one-earner households and twoearner households. Although the effect of income on distance for two-earner households is positive, it is small (0.023), and due to its large standard error (0.068) highly insignificant and therefore difficult to interpret (see column [7]). This is in line with theoretical considerations as for two-earner households the chosen residence location affects the commutes for both workers within the same household. If these two workplace locations are not close to each other, then the increase in commute of one worker may decrease the commute of the other worker. The effect for one earner households is positive and (almost) statistically significant at the 5\% level: it is 0.124 (s.e. 0.065), see column [4]. ${ }^{19}$ The latter elasticity is also somewhat higher than the elasticity estimated for all households (column [1]). So, our main result seems to be mainly driven by the effect of household income for one-earner households. $^{20}$

One may argue that above estimates do not capture long-run effects as the average workplace spell is only 3.9 years. We have therefore also estimated models for short (less than 5 years) and long (more than 5 years) workplace spells, see columns [2] and [3]. As one expects, for long spells the effect of income, 0.179 (s.e. 0.083), is substantially higher than for short spells, 0.088 (s.e. 0.049). This result also holds when we distinguish between one-earner and two-earner households (compare columns [5], [6], [8], [9]).

\footnotetext{
${ }^{18} 0.7=\log (2)-\log (1)$.

${ }^{19}$ For one-earner households, log of other members of the household income is assumed to be zero. Hence, the effect of the dummy of one-earner household cannot be easily interpreted.

${ }^{20}$ However, a t-test of equality of the one-earner and two-earners income elasticities indicates that equality cannot be rejected (1.07), so, in principle, the observed differences in elasticities by type of households may be spurious.
} 
Differences in commuting patterns by gender as a response to changes in income are shown in Table 2. The commute of females seems more responsive to household income than those of males. The female income elasticity of distance $(0.157$ with an s.e. of 0.055$)$ exceeds the male elasticity (0.037 with an s.e. of 0.063), see columns [1] and [4]. Again, these elasticities are likely underestimates of the long-run ones: for long spells, the elasticity is larger (0.289 with an s.e. of 0.107 for females and 0.081 with an s.e. of 0.121 for males, see columns [2] and [5]). The male income elasticity is now far from statistically significant. A t-test of equality of the male and female income elasticities indicates that equality is strongly rejected (16.469). Note that the effect for females is even larger than for one-earner households, see Table 1 columns [4]-[6]. Table 3 examines therefore further the effect of income on distance through gender for different household types. We emphasise however that the sample size of the subgroups is rather small. Nevertheless, these results support our previous conclusion that the effect of income on distance is sizeable for female singleearner households. Hence, the positive effect of income in Table 1, column [1] is mainly due to commuting behaviour of females belonging to one-earner households, see columns [1]-[3]. One explanation of females' larger income elasticities relates to their home responsibilities. In one-earner households, females may start holding less responsibilities within the household (e.g. as they may get a domestic helper), which allows them to work farther away from home.

The presence of a partner (controlling for single wage-earner and dual wage-earner households) has a significant positive effect in all analyses indicating that when an individual starts to cohabite with a partner, the commuting distance increases, so there is a tendency to move farther from the job for at least one of the members of the household. This is in line with standard urban economics theory, as the demand for housing increases with the presence of a partner. Conditional on having a partner, one-earner households have a longer commuting distance than two-earner households. This is also in line with urban economics theory, as two-earner households have a higher demand for commuting.

\subsubsection{Sensitivity analyses}

We subjected the results to a number of sensitivity analyses. For two-earner households, it may be 
useful distinguish between the effects of individual labour income and other household income. ${ }^{21}$ Furthermore, the effect of individual labour income may be due to a change in number of hours worked or due to a change in wages. Table A3 in the Appendix examines the effect of individual labour income on commuting distance through the sum of the effect of changes in hourly wages and changes in workhours as well as other household income. Standard F-tests support that the coefficients of $\log$ hours and $\log$ wage are the same. ${ }^{22}$ The effect of other household income, when controlling for individual labour income, is insignificant. ${ }^{23}$ This result is not so surprising in the light of earlier findings that income is particular relevant in one-earner households, but less relevant in two-earner households.

We have estimated models on a selective sample of workers for which changes in distance refer to workers that change residence in order to obtain long-run effects. To see the importance of this selection, we also estimated models including observations without a residential move. The signs of the effect of household income are the same, but the sizes of these effects are about 50 percent smaller than the ones discussed above $(0.058$ with s.e. $0.029 ; 0.065$ with s.e. 0.045 for one-earner households; 0.012 with s.e. 0.044 for two-earner households; 0.082 with s.e. 0.028 for females; 0.015 with s.e. 0.043 for males). Hence, to obtain long-run effects it is important to select households that move residence. This is in line with intuition.

When we exclude time-varying explanatory variables (except for year dummies), it appears that the estimates are similar to those reported above $(0.110$ with s.e. $0.041 ; 0.124$ with s.e. 0.066 for oneearner households; 0.022 with s.e. 0.069 for two-earner households; 0.138 with s.e. 0.052 for females; 0.052 with s.e. 0.062 for males). Hence, including time-varying explanatory variables does not appear to be relevant for the results. Furthermore, we are interested to know how important it is to keep workplace location constant, which was argued to be, at least in theory, an essential step in our

\footnotetext{
${ }^{21}$ Workhours may be endogenously chosen, as workers are likely heterogeneous in their preference for leisure time and therefore workhours. In Germany this may not be so relevant, because of constraints on total labour supply set by employers: collective bargaining agreements, as well as European Union labour laws. In addition, we use worker fixed effects which capture time-invariant unobserved workhours preferences of workers. Gutiérrez-i-Puigarnau and van Ommeren (2010) find a small effect of commuting distance on overall labour supply; which implies that, when examining the effect of labour income on distance, endogenous changes in workhours are likely not problematic.

${ }^{22} \mathrm{P}$-value of the F-test is 0.810 for all households, 0.603 for one-earner households and 0.700 for two-earner households.

${ }^{23}$ For one-earner households, we do not control for other household income, as it is almost always zero.
} 
methodology. To investigate this, we have estimated standard worker fixed effects model. We find that this strongly biases downwards the results $(0.051$ with s.e. 0.042 ; 0.069 with s.e. 0.061 for oneearner households; -0.005 with s.e. 0.072 for two-earner households; 0.115 with s.e. 0.055 for females; -0.011 with s.e. 0.062 for males). ${ }^{24}$

One may argue that an instrumental variable approach would be a good alternative to our estimation approach. For two-earner households, one may argue that other members' income is a suitable instrument for household income of two-earner households. The assumption that one has to make then is that controlling for household income and therefore the wage earners' own income, the individuals' commuting distance is exogenous with respect to other members 'household income. One advantage of this approach is that, if the instrument is valid, one obtains long-run effects, so one may apply the approach to the full sample of two-earner households, rather than on the selective sample we have used in the multivariate analysis. So, we estimate instrumental variables models based on equation (1) but do not allow for worker fixed effects but include many time-invariant variables (e.g. gender). A (robust) DWH exogeneity test, with an F-test of 76.57, leads to strong rejection of the null hypothesis that logarithm of household income is exogenous. This confirms our earlier claim that it is endogenous. The instrument is strong with an F-value of 6748. Interestingly, the IV estimate for twoearner households is small and statistically insignificant (0.054 with s.e. 0.030). Interestingly, the size of the effect is almost identical to the earlier obtained estimate for workplace spells longer than 5 years $(0.051$ with s.e. 0.119$)$. However, as the standard errors are large, these results are difficult to interpret.

\section{Conclusions}

The equilibrium relationship between income and the length of the commute is one of the most wellknown applications of urban economic theory. A priori, the sign of this relationship is ambiguous in the standard urban model that incorporates the value of time as part of the cost of commuting. This paper seeks to determine the (long-run) causal effect of income on commuting distance. The paper

\footnotetext{
${ }^{24}$ We have estimated standard cross-section models (OLS) with many controls. This results in a large upward bias in the estimates $(0.263$ with s.e. $0.013 ; 0.259$ with s.e. 0.016 for one-earner households; 0.260 with s.e. 0.021 for two-earner households; 0.270 with s.e. 0.017 for females; 0.246 with s.e. 0.018 for males). The most plausible explanation for this bias is reverse causation, so that it captures the labour market search effect. Workers with a longer commute are offered higher wages.
} 
addresses possible reverse causality bias by keeping workplace location constant. For Germany, we find a long-run income elasticity in the order of about 0.11 to 0.18 , which is not negligible. A positive relationship particularly applies to one-earner households and female workers. At least for Germany, these results suggest, as workers tend to commute to workplace locations where land prices are higher, which suggests that the income elasticity for residential space exceeds the income elasticity for commuting costs.

In the current paper, we ignored the role of residential amenities. As is well known, the demand for residential amenities depends positively on household income. So, our interpretation of the results may be argued to hold only if residential amenities are randomly distributed over space. In Germany however, most workplace locations and residential amenities tend to be in the same historic city centres, so our estimates are most likely underestimates (as a longer commuting distance tends to be negatively correlated with residential amenities). However, as historic city centres are rather small in Germany, the bias in our estimates is likely limited. Our results do imply that in the absence of historic city centre amenities or other amenities close to workplace centres, rich households tend to move farther away from the city centre, as is observed in most US cities (Brueckner, et al. 1999). We believe our results are interesting because it contrast the seminal paper by Wheaton (1977) which states that the standard urban economics model accidentally does not explain variation in household income over space. We believe that our results are also consistent with the evidence that aggregate income growth (so at the level of the region or even nation) encourages suburbanisation (Anas, Arnott and Small, 1998).

\section{References}

Alonso, W. (1964), Location and land use, Harvard University Press, Cambridge, USA

Anas, A., R. Arnott and K.A. Small (1998), Urban Spatial Structure, Journal of Economic Literature, $36,3,1426-1464$

Beckman, M.J. (1974), Spatial equilibrium in the housing market, Journal of Urban Economics, 1, 1, 99-107

Benito, A. and A.J. Oswald (1999), Commuting in Great Britain in the 1990s, mimeo

Brueckner, J.K. (2000), Urban sprawl: diagnosis and remedies, International Regional Science Review, 23, 2, 160-171

Brueckner, J.K., J.-F. Thisse and Y. Zenou (1999), Why is central Paris rich and downtown Detroit 
poor: an amenity-based theory, European Economic Review, 43, 1, 91-107

Fujita, M. (1989), Urban economic theory, Cambridge University Press, Cambridge, UK

Fujita, M. and H. Ogawa (1982), Multiple equilibria and structural transition of non-monocentric urban configurations, Regional Science and Urban Economics, 12, 2, 161-196

Fujita, M., J-F. Thisse and Y. Zenou (1997), On the endogeneous formation of secondary employment centers in a city, Journal of Urban Economics, 41, 3, 337-357

Glaeser, E.L., M.E. Kahn and J. Rappaport (2008), Why do the poor live in cities? The role of public transportation, Journal of Urban Economics, 63, 1, 1-24

Gutiérrez-i-Puigarnau, E. and J.N. van Ommeren (2010), Labour supply and commuting, Journal of Urban Economics, 68, 1, 82-89

Haisken-DeNew, J.P. and M.H. Hahn (2010), PanelWhiz: efficient data extraction of complex panel data sets - An example using the German SOEP, Journal of Applied Social Science Studies, 130, 4, 643-654

Henderson, J. (1977), Economic theory and the cities, Academic Press, New York, USA

Hockman, O. and H. Ofek (1977), The value of time in consumption and residential location in an urban setting, American Economic Review, 67, 5, 996-1003

Lucas, R.E., Jr. and E. Rossi-Hansberg (2002), On the internal structure of cities, Econometrica, 70, $4,1445-1476$

Manning, A. (2003), The real thin theory: monopsony in modern labour markets, Labour Economics, $10,105-131$

Muth, R.F. (1969), Cities and housing, University of Chicago Press, Chicago, USA

O’Sullivan, A. (2009), Urban economics, (seventh edition), McGraw-Hill, Boston, USA

Persky, J. (1990), Suburban income inequality: three theories and a few facts, Regional Science and Urban Economics, 20, 1, 125-137

Rouwendal, J. and P. Rietveld (1994), Changes in commuting distances of Dutch households, Urban Studies, 31, 9, 1545-1557

Rouwendal, J. and J.N. van Ommeren (2007), Recruitment in a Monopsonistic Labour Market: Will Travel Costs Be Reimbursed?, Working Paper

Simonsohn, U. (2006), New Yorkers commute more everywhere: contrast effects in the field, Review of Economics and Statistics, 88, 1, 1-9

Straszheim, M. (1987), The theory of urban residential location, in E.S. Mills (ed.), Handbook of 
Regional and Urban Economics, Amsterdam, Elsevier, 717-757

Timothy, D. and W.C. Wheaton (2001), Intra-urban wage variation, employment location, and commuting time, Journal of Urban Economics, 50, 2, 338-366

Van Ommeren, J.N and P. Rietveld (2005), The commuting time paradox, Journal of Urban Economics, 58, 3, 437-454

Van Ommeren J.N. and M. van Leuvensteijn (2005), New evidence of the effect of transaction costs on residential mobility, Journal of Regional Science, 45, 4, 681-702

Van Ommeren, J.N., P. Rietveld and P. Nijkamp (1999) Job mobility, residential and commuting: a search perspective, Journal of Urban Economics, 46, 2, 230-253

Weinberg, D., J. Friedman and S. Mayo (1981), Intraurban residential mobility: the role of transactions costs, market imperfections, and household disequilibrium, Journal of Urban Economics, 9, 3, 332-348

Wheaton, W. (1977), Income and urban residence: an analysis of consumer demand for location, American Economic Review, 67, 4, 620-631

White, M.J. (1977), A model of residential location choice and commuting by men and women workers, Journal of Regional Science, 17, 1, 41-52

White, M.J. (1988), Location choice and commuting behavior in cities with decentralized employment, Journal of Urban Economics, 24, 2, 129-152

Zax, J.S. (1991), The substitution between moves and quits, The Economic Journal, 101, 409, 15101521 

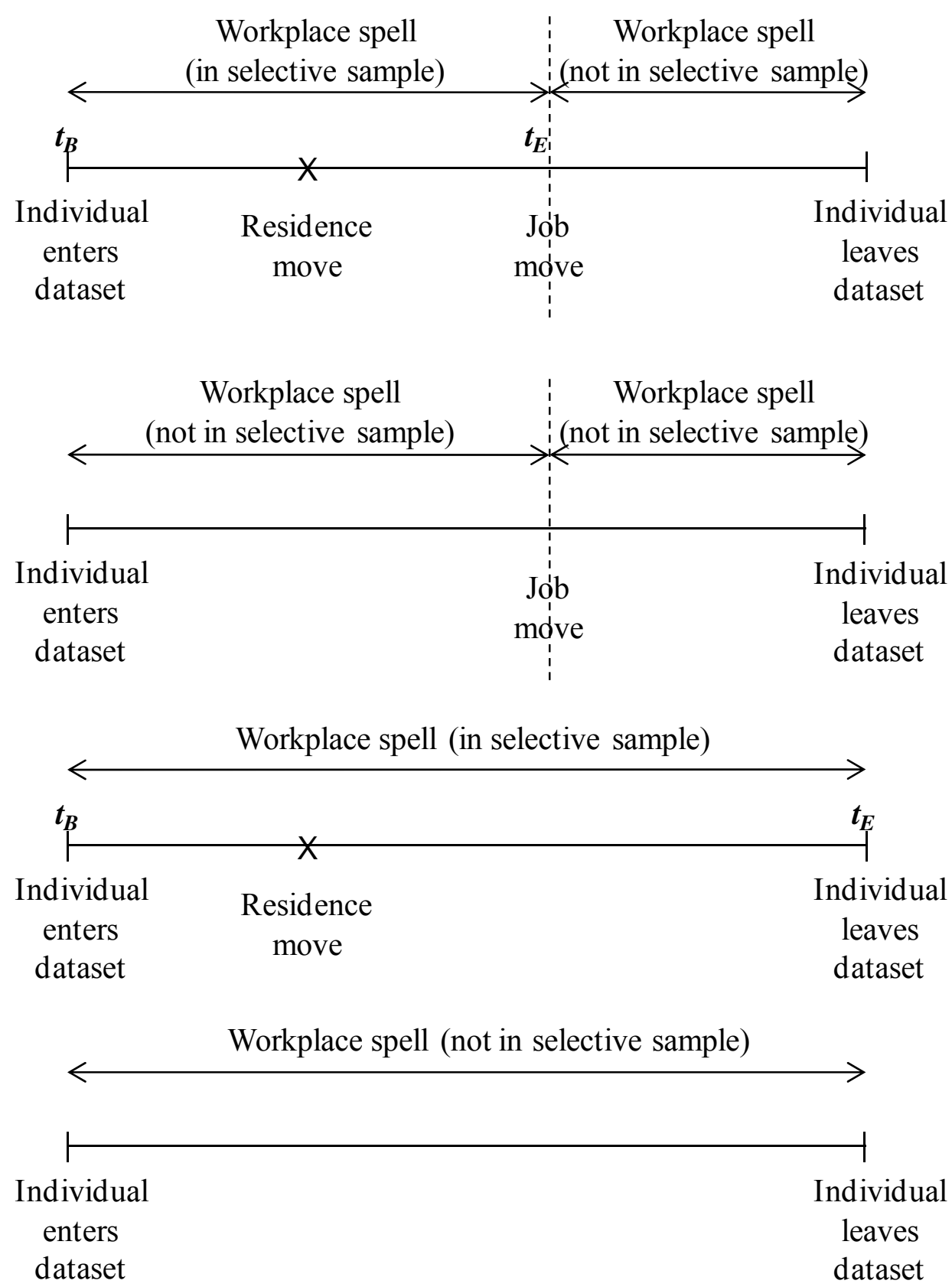

Figure 1. Example of (Censored) Workplace Spells

Note: $t_{B}$ and $t_{E}$ denote the beginning and the end of a workplace spell respectively. 


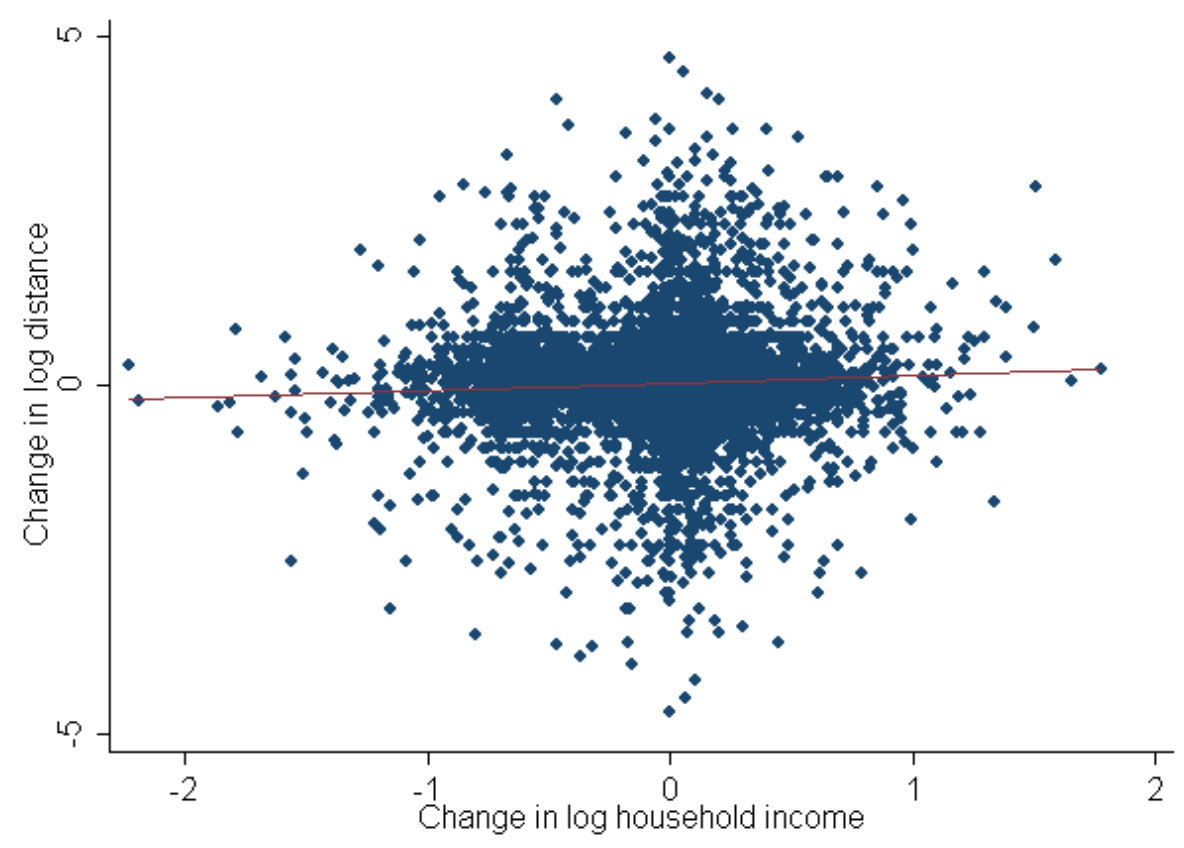

Figure 2. Change in Distance by Change in Household Income for Long Workplace Spells ( $>5$ years)

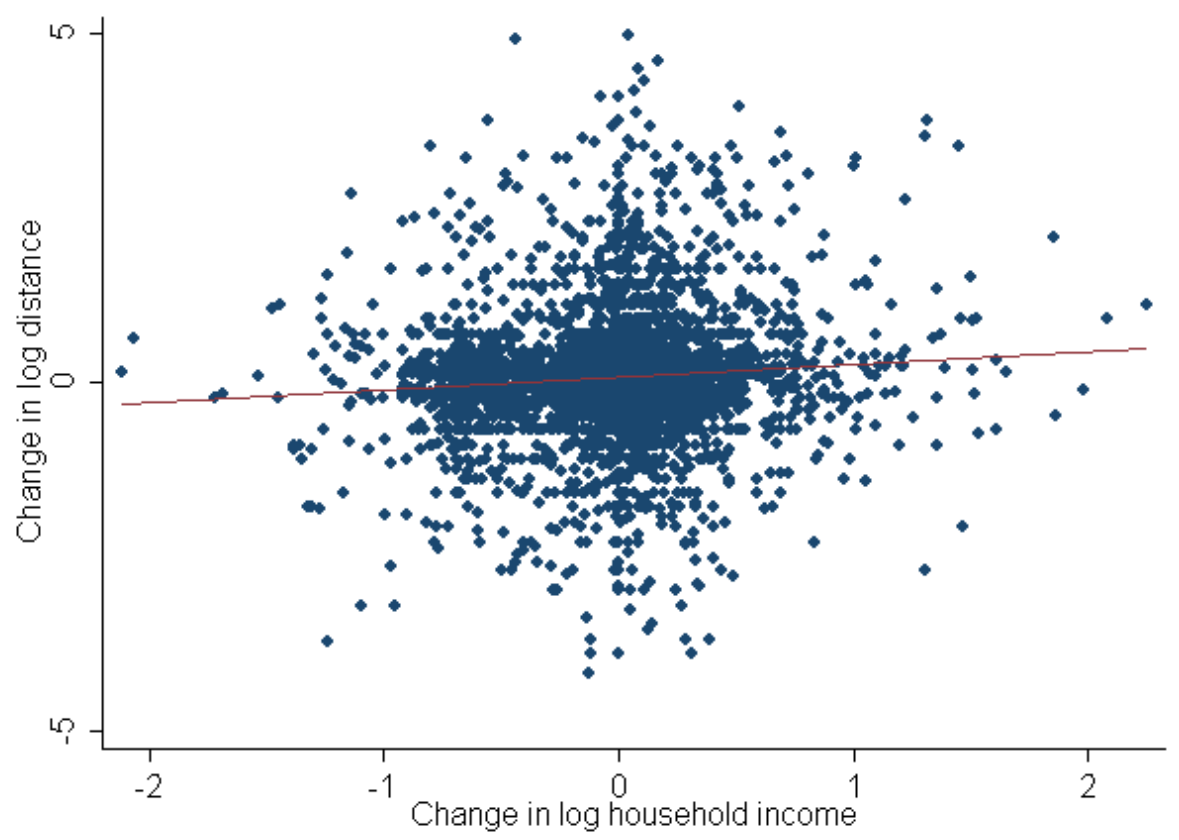

Figure 3. Change in Distance by Change in Household Income for Short Workplace Spells ( $\leq 5$ years) 
Table 1. Estimates of Changes in Logarithm of Commuting Distance

\begin{tabular}{|c|c|c|c|c|c|c|c|c|c|}
\hline & [1] & {$[2]$} & [3] & [4] & 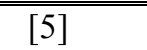 & [6] & [7] & [8] & [9] \\
\hline & \multicolumn{3}{|c|}{ all households } & \multicolumn{3}{|c|}{ 1-earner household } & \multicolumn{3}{|c|}{ 2-earner households } \\
\hline & all years & $>5$ years & $\leq 5$ years & all years & $>5$ years & $\leq 5$ years & all years & $>5$ years & $\leq 5$ years \\
\hline \multirow{2}{*}{ household income (in log) } & $0.108^{* *}$ & $0.179^{* *}$ & $0.088^{*}$ & $0.124^{*}$ & $0.262^{*}$ & 0.070 & 0.023 & 0.051 & 0.002 \\
\hline & $(0.042)$ & $(0.083)$ & $(0.049)$ & $(0.065)$ & $(0.139)$ & $(0.074)$ & $(0.068)$ & $(0.119)$ & $(0.082)$ \\
\hline \multirow{2}{*}{ one-earner household } & $0.115^{* *}$ & 0.079 & $0.123^{*}$ & & & & & & \\
\hline & $(0.056)$ & $(0.106)$ & $(0.066)_{* *}$ & & & & & & \\
\hline \multirow{2}{*}{ presence of partner } & $0.325^{* *}$ & 0.167 & $0.364^{* *}$ & $0.372^{* *}$ & 0.177 & $0.487^{* *}$ & & & \\
\hline & $(0.075)$ & $(0.133)$ & $(0.090)$ & $(0.153)$ & $(0.247)$ & $(0.176)$ & & & \\
\hline \multirow{2}{*}{ num. of children } & -0.020 & $-0.076^{*}$ & 0.026 & 0.004 & -0.036 & 0.017 & 0.008 & -0.061 & 0.045 \\
\hline & $(0.029)$ & $(0.045)$ & $(0.039)$ & $(0.079)$ & $(0.107)$ & $(0.107)$ & $(0.039)$ & $(0.058)$ & $(0.052)$ \\
\hline \multirow{2}{*}{ female with child } & -0.039 & 0.041 & -0.047 & 0.151 & -0.054 & 0.340 & -0.250 & 0.036 & $-0.372^{*}$ \\
\hline & $(0.088)$ & $(0.121)$ & $(0.125)$ & $(0.167)$ & $(0.185)$ & $(0.234)$ & $(0.155)$ & $(0.172)$ & $(0.215)$ \\
\hline \multirow{2}{*}{ female partner } & $-0.230^{* *}$ & -0.115 & $-0.254^{* *}$ & 0.117 & 0.521 & -0.185 & & & \\
\hline & $(0.090)$ & $(0.148)$ & $(0.110)$ & $(0.353)$ & $(0.642)$ & $(0.339)$ & & & \\
\hline firm size dummies (6) & included & included & included & included & included & included & included & included & included \\
\hline year dummies (15) & included & included & included & included & included & included & included & included & included \\
\hline num. observations & 4,957 & 1,031 & 3,926 & 2,117 & 370 & 1,747 & 2,840 & 661 & 2,179 \\
\hline adjusted $\mathrm{R}^{2}$ & 0.051 & 0.108 & 0.043 & 0.040 & 0.064 & 0.043 & 0.060 & 0.166 & 0.044 \\
\hline
\end{tabular}

Notes: ${ }^{* *},{ }^{*}$ indicate that the estimates are significantly different than zero at the 0.05 and 0.1 level, respectively. Robust standard errors are in parentheses. 
Table 2. Estimates of Changes in Logarithm of Commuting Distance by Gender

\begin{tabular}{|c|c|c|c|c|c|c|}
\hline & all years & $\begin{array}{l}{[2]} \\
\text { females } \\
>5 \text { years }\end{array}$ & $\begin{array}{l}{[3]} \\
\leq 5 \text { years }\end{array}$ & $\begin{array}{l}{[4]} \\
\text { all years }\end{array}$ & $\begin{array}{l}5] \\
\text { males } \\
>5 \text { years }\end{array}$ & $\leq 5$ years \\
\hline & $0.157^{* *}$ & $0.289^{* *}$ & $0.103^{*}$ & 0.037 & 0.081 & 0.036 \\
\hline household income (in log) & $(0.055)$ & $(0.107)$ & $(0.063)$ & $(0.063)$ & $(0.121)$ & $(0.074)$ \\
\hline one-earner household & 0.211 & 0.395 & 0.131 & $0.100^{*}$ & 0.020 & $0.124^{*}$ \\
\hline one-eanter housenota & $(0.163)$ & $(0.322)$ & $(0.204)$ & $(0.061)$ & $(0.116)$ & $(0.071)$ \\
\hline presence of partner & $\begin{array}{c}0.202 \\
(0.170)\end{array}$ & $\begin{array}{c}0.357 \\
(0.335)\end{array}$ & $\begin{array}{c}0.129 \\
(0.204)\end{array}$ & $\begin{array}{c}0.269^{* *} \\
(0.079)\end{array}$ & $\begin{array}{c}0.106 \\
(0.139)\end{array}$ & $\begin{array}{l}0.312^{* *} \\
(0.094)\end{array}$ \\
\hline num. of children & $\begin{array}{l}-0.056 \\
(0.045)\end{array}$ & $\begin{array}{l}-0.137^{* * *} \\
(0.064)\end{array}$ & $\begin{array}{c}0.013 \\
(0.120)\end{array}$ & $\begin{array}{l}-0.031 \\
(0.049)\end{array}$ & $\begin{array}{c}0.002 \\
(0.041)\end{array}$ & $\begin{array}{l}-0.016 \\
(0.031)\end{array}$ \\
\hline $\begin{array}{l}\text { firm size dummies (6) } \\
\text { year dummies (15) }\end{array}$ & $\begin{array}{l}\text { included } \\
\text { included }\end{array}$ & $\begin{array}{l}\text { included } \\
\text { included }\end{array}$ & $\begin{array}{l}\text { included } \\
\text { included }\end{array}$ & $\begin{array}{l}\text { included } \\
\text { included }\end{array}$ & $\begin{array}{l}\text { included } \\
\text { included }\end{array}$ & $\begin{array}{l}\text { included } \\
\text { included }\end{array}$ \\
\hline num. observations & 2,917 & 610 & 2,307 & 1,020 & 179 & 841 \\
\hline adjusted $R^{2}$ & 0.055 & 0.171 & 0.035 & 0.108 & 0.055 & 0.055 \\
\hline
\end{tabular}

Notes: ${ }^{* *},{ }^{*}$ indicate that the estimates are significantly different than zero at the 0.05 and 0.1 level, respectively. Standard errors are in parentheses. 
Table 3. Estimates of Changes in Logarithm of Commuting Distance by Gender and by Type of Household

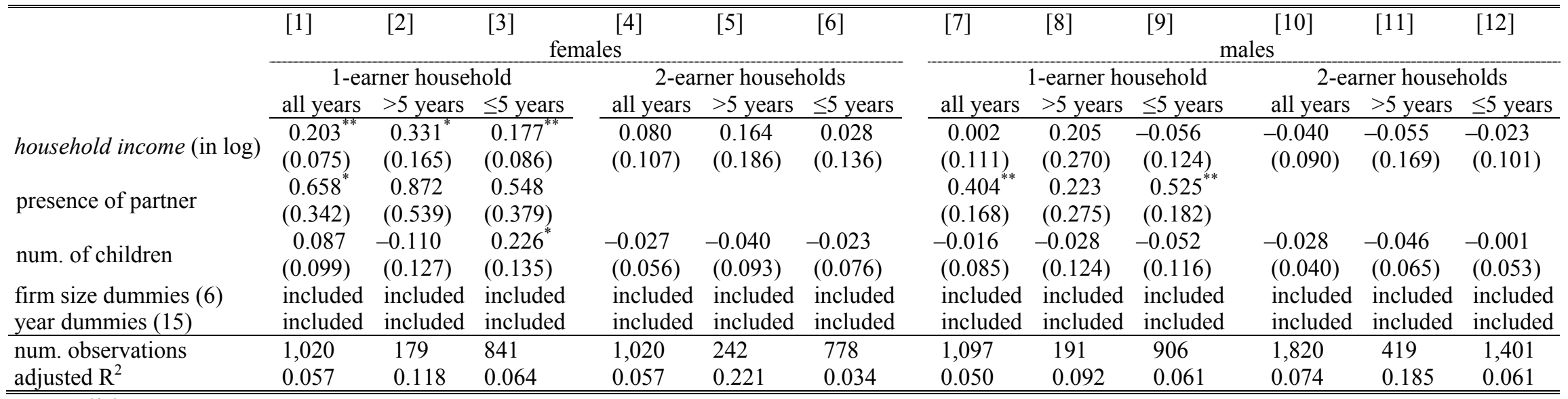

Notes: ${ }^{* *},{ }^{*}$ indicate that the estimates are significantly different than zero at the 0.05 and 0.1 level, respectively. Robust standard errors are in parentheses. 
Table A1. Descriptive Statistics

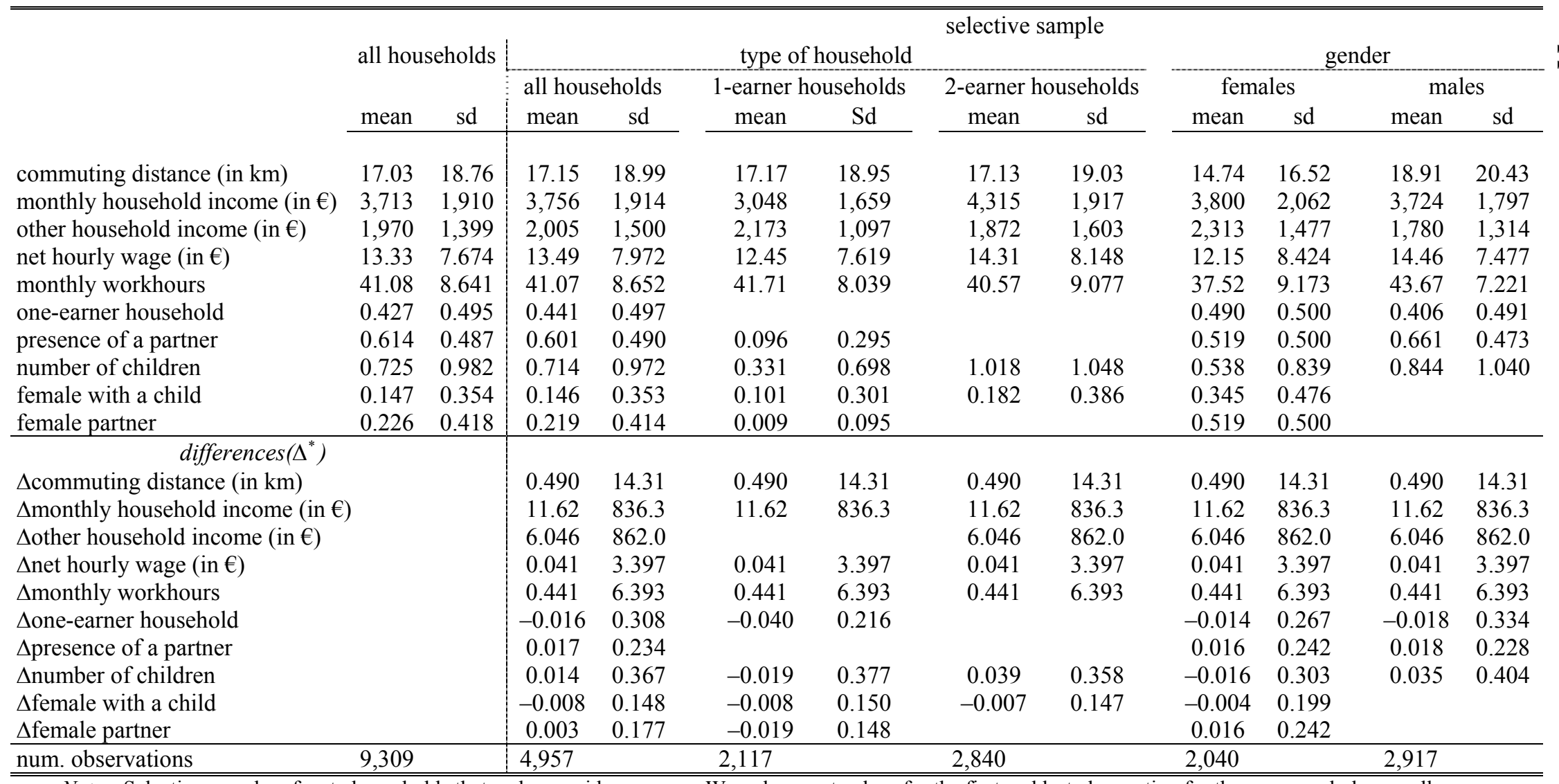

Notes: Selective sample refers to households that make a residence move. We only report values for the first and last observation for the same workplace spell.

${ }^{*}$ refers to changes measured at the beginning and the end of a workplace spell. 
First Stage Results of Household Income IV-procedure: Two-Earner Household

\begin{tabular}{|c|c|}
\hline & all workers \\
\hline other household income (in log) instrument & $0.247(0.002)^{* *}$ \\
\hline female & $-0.121(0.004)^{* *}$ \\
\hline num. of children & $0.031(0.002)^{* *}$ \\
\hline female with child & $-0.035(0.005)^{* *}$ \\
\hline age & $0.022(0.001)^{* *}$ \\
\hline$\left(\operatorname{age}^{2}\right) / 100$ & $-0.012(0.002)^{* *}$ \\
\hline education dummies (5) & included \\
\hline employee & $-0.129(0.009)^{* *}$ \\
\hline type of employment dummies (4) & included \\
\hline residence region dummies (2) & included \\
\hline province dummies (14) & included \\
\hline workplace region dummies (4) & included \\
\hline firm size dummies (6) & included \\
\hline year dummies (15) & included \\
\hline constant & $5.732(0.035)^{* *}$ \\
\hline num. observations & 29,489 \\
\hline
\end{tabular}

Notes: Other members of the household monthly net income including non-labour income. Type of employee dummies include civil servant, blue collar, white collar or unknown. The reference category for employee is 'self-employed'. ${ }^{* *},{ }^{*}$ indicate that the estimates are significantly different than zero at the 0.05 and 0.1 level, respectively. Standard errors are in parentheses. 
Table A3. Estimates of Changes in Logarithm of Commuting Distance: Distinguishing between Individual Income (Wages and Workhours) and Other Household Income

\begin{tabular}{|c|c|c|c|}
\hline & $\begin{array}{l}{[1]} \\
\text { all households }\end{array}$ & $\begin{array}{l}{[2]} \\
1 \text {-earner household }\end{array}$ & $\begin{array}{l}{[3]} \\
\text { 2-earner households }\end{array}$ \\
\hline net hourly wage (in log) & $\begin{array}{l}0.137^{* *} \\
(0.056)\end{array}$ & $\begin{array}{l}0.164 \\
(0.113)\end{array}$ & $\begin{array}{l}0.047 \\
(0.075)\end{array}$ \\
\hline monthly workhours (in log) & $\begin{array}{l}0.151^{* *} \\
(0.072)\end{array}$ & $\begin{array}{l}0.102 \\
(0.141)\end{array}$ & $\begin{array}{l}0.020 \\
(0.096)\end{array}$ \\
\hline other household income (in log) & $\begin{array}{l}0.022 \\
(0.019)\end{array}$ & & $\begin{array}{l}0.012 \\
(0.023)\end{array}$ \\
\hline one-earner household & $\begin{array}{l}0.047 \\
(0.065)\end{array}$ & & \\
\hline presence of partner & $\begin{array}{l}0.273^{* *} \\
(0.077)\end{array}$ & $\begin{array}{l}0.338^{* *} \\
(0.155)\end{array}$ & \\
\hline num. of children & $\begin{array}{l}-0.024 \\
(0.029)\end{array}$ & $\begin{array}{l}0.001 \\
(0.079)\end{array}$ & $\begin{array}{l}0.001 \\
(0.039)\end{array}$ \\
\hline female with child & $\begin{array}{l}0.003 \\
(0.087)\end{array}$ & $\begin{array}{l}0.177 \\
(0.164)\end{array}$ & $\begin{array}{l}-0.209 \\
(0.146)\end{array}$ \\
\hline female partner & $\begin{array}{l}-0.215^{* *} \\
(0.089)\end{array}$ & $\begin{array}{l}0.088 \\
(0.358)\end{array}$ & \\
\hline $\begin{array}{l}\text { firm size dummies (6) } \\
\text { year dummies (15) }\end{array}$ & $\begin{array}{l}\text { included } \\
\text { included }\end{array}$ & $\begin{array}{l}\text { included } \\
\text { included }\end{array}$ & $\begin{array}{l}\text { included } \\
\text { included }\end{array}$ \\
\hline num. observations & 4,957 & 2,117 & 2,840 \\
\hline
\end{tabular}

Notes: The sum of log of net hourly wage rate, log of monthly workhours and log of other members of the household monthly net income equals log monthly net household income. For one-earner households, log of other members of the household income equals zero; hence, the dummy of one-earner household cannot be interpreted. ${ }^{*}{ }^{*}$ indicate that the estimates are significantly different than zero at the 0.05 and 0.1 level, respectively. Standard errors are in parentheses. 